\title{
Synthesis and Spectral-Luminescent Properties of Polynuclear Lanthanide Complexes with Functionalized Calix[4]arenes
}

\author{
Olga V. Snurnikova, Aleksandr P. Lukyanenko, Elena A. Alekseeva, \\ Yuriy V. Korovin, and Natalya V. Rusakova ${ }^{\circledR}$ \\ A.V. Bogatsky Physico-Chemical Institute of National Academy of Sciences of Ukraine, 65080 Odessa, Ukraine \\ @Corresponding author E-mail: lanthachem@ukr.net
}

\begin{abstract}
The mono- and heteronuclear lanthanide-containing complexes on the basis of 1,3-disubstituted p-tert-butylcalix[4] arenes modified with macrocyclic (porphyrin) and acyclic (benzimidazole) nitrogen-containing fragments were investigated. The optimal conditions of synthesis, compositions and structures of lanthanide complexes with functionalized calix[4] arenes were determined. The influence of the structure of compounds on the spectral-luminescent properties of both the ligands and their complexes was analyzed.
\end{abstract}

Keywords: Calix[4]arenes, porphyrins, lanthanide-containing complexes, $4 f$-luminescence.

\section{Introduction}

Calix[4]arenes are macrocyclic compounds which are products of the cyclic oligomerization of phenol and formaldehyde..$^{[1]}$ Calix[4]arenes can form supramolecular "host-guest" complexes with metal ions or small organic molecules. The advantage of use of calix[4]arene platform in the structure of molecular receptors is their preorganization, which provides a favourable position of functional groups and facilitates the formation of complexes. ${ }^{[2]}$ In particular, this principle is implemented in 1,3-disubstituted calix[4] arenes, in which the unsubstituted hydroxyl-groups fix the position of functional groups through hydrogen bonds. This type of ligands is called "molecular tweezers". ${ }^{[3]}$ It is known $^{[4,5]}$ that diamide derivatives of calix[4]arenes form stable complexes with lanthanide ions, alkali and transition metals due to the presence of a cavity formed by donor atoms of phenol, ether and amide groups. The combination of calix[4]arene macrocycle and substituents containing additional coordination centers (for example, imidazole) leads to obtaining of polyfunctional compounds. In complexes with these ligands the metal ion, depending on its nature, can coordinate with oxygen atoms of phenolic, carbonyl, ether groups, or form complexes with nitrogen-containing substituents. At the same time, the porphyrin-substituted calix[4]arenes, maintaining the marked features, represent the ligands with specific complexation and spectral-luminescent properties. These properties are due to the fact that they contain two chromophoric macrocycles, which absorb energy in the ultraviolet and visible spectral regions, as well as two types of coordination centers and are characterized by unique spatial structure. Thus, functionalized calix[4]arenes can be used as effective "building" blocks in the homo- and heteronuclear assembles. ${ }^{[6]}$

The development of synthesis of mono- and heteronuclear lanthanide-containing complexes on the basis of 1,3-disubstituted $p$-tert-butylcalix[4]arenes modified with porphyrin and benzimidazole fragments (Figure 1), analysis of the relationship between spectral-luminescent properties of these compounds and their structure were the purpose of this work.
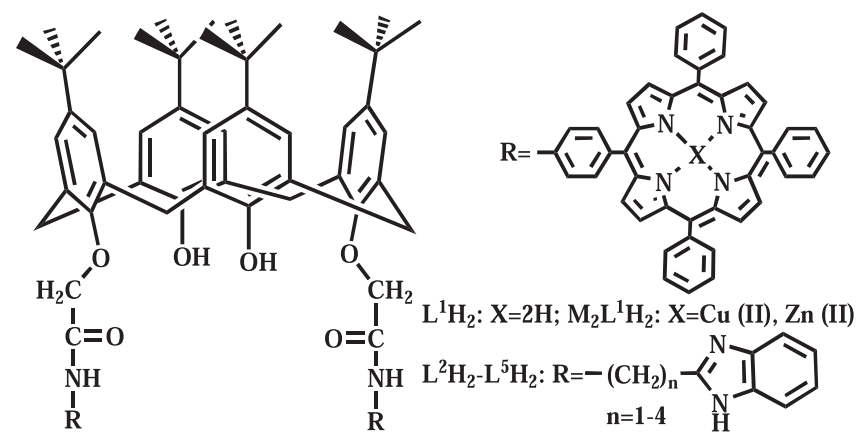

Figure 1. Structures of ligands and complexes.

\section{Experimental}

Ytterbium(III), erbium(III) and lutetium(III) oxides (99.98\% - 99.99\%), copper(II) and zinc(II) chlorides were purchased from Aldrich (Gillingham, Dorset) and used without further purification. Chlorides of lanthanides were prepared from corresponding oxides. The rest of chemicals were analytically pure in quality. Syntheses of compounds $\mathrm{L}^{1} \mathrm{H}_{2}-\mathrm{L}^{5} \mathrm{H}_{2}$ were realized according to the known methods. ${ }^{[7,8]}$ All ligands and complexes were isolated in solid state and characterized by elemental analysis, IR-, UV-vis-, ${ }^{1} \mathrm{H}$ NMR-spectroscopy and mass-spectrometry.

Mass spectra MALDI were recorded on Autoflex II spectrometer (Varian BV, Middelburg) using method of laser activated matrix desorption/ionization (MALDI), and laser desorption/ionization (LDI). Mass spectra FAB were registered on Varian MAT CH-112 spectrometer (Varian BV, Middelburg) using $m$-nitrobenzyl alcohol as the matrix. ${ }^{1} \mathrm{H}$ NMR spectra were recorded on Bruker Avance-300 (300 MHz) in $\mathrm{CDCl}_{3}$. UV-vis spectra were recorded on a Specord M40 UV/VIS (Carl Zeiss, Jena, Germany) spectrometer. Emission and excitation spectra were measured using Horiba Jobin Yvon Fluorolog 3-22 spectrofluorimeter equipped for measurements at both RT and 77 K (detectors Hamamatsu R928 
and DSS-IGA020L Electro-Optical Systems, Inc. for visible and NIR domain, respectively). The excitation source was a $450 \mathrm{~W}$ Xe arc lamp. The relative quantum yields of $4 f$-luminescence $(\varphi)$ for the ytterbium complexes were calculated using $\mathrm{Zn}$ tetraphenylporphyrin as a standard, the quantum yield of which is $0.0315 .^{[9]}$

General procedure for the synthesis of mononuclear lanthanide- containing complexes on the basis of ligands $\mathrm{LnL}^{1} \mathrm{Cl}-$ $\mathrm{LnL}^{5} \mathrm{Cl}$ : lanthanide chloride $\left(0.11 \mathrm{mmol} \mathrm{LnCl}_{3} \cdot 6 \mathrm{H}_{2} \mathrm{O}\right)$ was refluxing with $0.5 \mathrm{ml}$ triethyl orthoformiate in dry acetonitrile $(10 \mathrm{ml})$ for $30 \mathrm{~min}$. Subsequently, a solution of ligand $(0.10 \mathrm{mmol}$ in $5 \mathrm{ml}$ acetonitrile) was added and reflux was continued for 3.5-4 h. Then, the reaction mixture was cooled to the room temperature, and diethyl ether was added $(50 \mathrm{ml})$. The precipitate was filtered, washed with water, and dried at a temperature of $110-120^{\circ} \mathrm{C}$ for $8-10 \mathrm{~h}$. As an example, the data for the complexes $\mathrm{LuL}^{1} \mathrm{Cl}$ and $\mathrm{LuL}_{2} \mathrm{Cl}$ are given below.

$\mathrm{LuL}^{1} \mathrm{Cl}\left(0.200\right.$ g, 93 \%). M.p. $>350^{\circ} \mathrm{C}\left(\mathrm{CH}_{3} \mathrm{CN}\right) . \mathrm{m} / \mathrm{z}$ (MALDI) (\%) 2197.0 (95) calcd. for $\mathrm{C}_{136} \mathrm{H}_{116} \mathrm{~N}_{10} \mathrm{ClO}_{6} \mathrm{Lu} 2196.86$. UV-vis (DMF) $\lambda_{\text {max }}(\lg \varepsilon) \mathrm{nm}: 280$ (3.42), 312 (2.48), 418 (5.1), 516 (4.2), 552 (3.75), 591 (3.46), 648 (3.43). ${ }^{1} \mathrm{H} \mathrm{NMR}\left(\mathrm{CDCl}_{3}, 300 \mathrm{~K}\right) \delta_{\mathrm{H}}$ ppm: -2.81 (4H, s, $\left.\mathrm{NH}_{\text {Porph }}\right), 0.97\left(18 \mathrm{H}, \mathrm{s},{ }^{\mathrm{t}} \mathrm{Bu}\right), 1.26\left(18 \mathrm{H}, \mathrm{s},{ }^{\mathrm{t}} \mathrm{Bu}\right)$, $3.40\left(4 \mathrm{H}, \mathrm{d}, \mathrm{ArCH}_{\mathrm{eq}} \mathrm{Ar}, J=13.4\right), 3.75\left(4 \mathrm{H}, \mathrm{d}, \mathrm{ArCH}_{\mathrm{ax}} \mathrm{Ar}, J=13.4\right)$, $4.57\left(4 \mathrm{H}, \mathrm{s}, \mathrm{OCH}_{2}\right), 6.81(4 \mathrm{H}, \mathrm{s}, \mathrm{ArH}), 7.05(4 \mathrm{H}, \mathrm{s}, \mathrm{ArH}), 7.68-7.80$ $\left(20 \mathrm{H}, \mathrm{m}, \mathrm{CH}_{\text {Ph-Porph }}\right), 8.12-8.18\left(10 \mathrm{H}, \mathrm{m}, \mathrm{CH}_{\text {Ph.Porph }}\right), 8.25(8 \mathrm{H}, \mathrm{d}$, $\left.\mathrm{CH}_{\text {Porph. }}\right), 8.73\left(8 \mathrm{H}, \mathrm{s}, \mathrm{CH}_{\text {Ph.-Porph }}\right), 8.86-8.88\left(4 \mathrm{H}, \mathrm{m}, \mathrm{CH}_{\text {Porph }}\right), 8.93$ (2H, d, NHCO), 9.17 (4H, d, $\mathrm{CH}_{\text {Porph }}$ ).

$\mathrm{LuL}^{2} \mathrm{Cl}\left(0.105\right.$ g, 87\%). M.p. $328-330^{\circ} \mathrm{C}\left(\mathrm{CH}_{3} \mathrm{CN}\right) . \mathrm{m} / \mathrm{z}(\mathrm{FAB})$ (\%): 1233 (98) calcd. for $\mathrm{C}_{64} \mathrm{H}_{72} \mathrm{~N}_{6} \mathrm{ClO}_{6} \mathrm{Lu} 1231.71$. UV-vis (DMF) $\lambda_{\max }(\lg \varepsilon) \mathrm{nm}: 280$ (4.19), 286 (4.20), 316 (3.75). ${ }^{1} \mathrm{H} \mathrm{NMR}\left(\mathrm{CDCl}_{3}\right.$, $300 \mathrm{~K}) \delta_{\mathrm{H}} \mathrm{ppm}: 0.96\left(18 \mathrm{H}, \mathrm{s},{ }^{\mathrm{t}} \mathrm{Bu}\right), 1.26\left(18 \mathrm{H}, \mathrm{s},{ }^{\mathrm{t}} \mathrm{Bu}\right), 3.30(4 \mathrm{H}, \mathrm{d}$, $\left.\mathrm{ArCH}_{\mathrm{eq}} \mathrm{Ar}, J=13.4\right), 4.00\left(4 \mathrm{H}, \mathrm{d}, \mathrm{ArCH}_{\mathrm{ax}} \mathrm{Ar}, J=13.4\right), 4.50(4 \mathrm{H}, \mathrm{s}$, $\left.\mathrm{OCH}_{2}\right), 4.94\left(4 \mathrm{H}, \mathrm{s}, \mathrm{NCH}_{2}\right), 6.81(4 \mathrm{H}, \mathrm{s}, \mathrm{ArH}), 7.03(4 \mathrm{H}, \mathrm{s}, \mathrm{ArH})$, 7.22-7.24 (4H, m, $\left.\mathrm{H}_{\text {bzim. }}\right), 7.54-7.56\left(4 \mathrm{H}, \mathrm{m}, \mathrm{H}_{\text {bzim }}\right), 8.48(2 \mathrm{H}, \mathrm{s}$, $\left.\mathrm{NH}_{\text {imid }}\right), 9.21(2 \mathrm{H}, \mathrm{t}, \mathrm{NH})$.

The binuclear complexes in which the lanthanide ion is coordinated by the nitrogen atoms of porphyrins $\left(\mathrm{Ln}_{2} \mathrm{~L}^{1} \mathrm{Cl}_{2}\right)$ were prepared similar to $\mathrm{L}^{1} \mathrm{H}_{2}{ }^{[7]}$ from corresponding porphyrinates.

$\mathrm{Lu}_{2} \mathrm{~L}^{1} \mathrm{Cl}_{2}(0.240 \mathrm{~g}, 70 \%)$. M.p. $>350^{\circ} \mathrm{C}\left(\mathrm{CH}_{2} \mathrm{Cl}_{2}\right) . \mathrm{m} / z$ (MALDI) (\%): 2404.9 (95) calcd. for $\mathrm{C}_{136} \mathrm{H}_{114} \mathrm{~N}_{10} \mathrm{Cl}_{2} \mathrm{O}_{6} \mathrm{Lu}_{2}$ 2405.26. UV-vis (DMF) $\lambda_{\text {max }}$ (lge) nm: 278 (3.82), 425 (4.90), 557 (3.52), 595 (3.12). ${ }^{1} \mathrm{H}$ NMR $\left(\mathrm{CDCl}_{3}, 300 \mathrm{~K}\right) \delta_{\mathrm{H}} \mathrm{ppm}: 1.18\left(18 \mathrm{H}, \mathrm{s},{ }^{\mathrm{t}} \mathrm{Bu}\right), 1.32(18 \mathrm{H}$, s, $\left.{ }^{\mathrm{Bu}}\right), 3.49\left(4 \mathrm{H}, \mathrm{d}, \mathrm{ArCH}_{\mathrm{eq}} \mathrm{Ar}, J=13.1\right), 4.20\left(4 \mathrm{H}, \mathrm{d}, \mathrm{ArCH}_{\mathrm{ax}} \mathrm{Ar}\right.$, $J=12.9), 4.92\left(4 \mathrm{H}, \mathrm{s}, \mathrm{OCH}_{2}\right), 7.15(4 \mathrm{H}, \mathrm{s}, \mathrm{ArH}), 7.23(4 \mathrm{H}, \mathrm{s}, \mathrm{ArH})$, 7.51-7.70 (20H, m, $\left.\mathrm{CH}_{\text {Ph.-Porph }}\right), 8.12-8.18\left(10 \mathrm{H}, \mathrm{m}, \mathrm{CH}_{\text {Ph.Porph. }}\right), 8.27$ $\left(8 \mathrm{H}, \mathrm{d}, \mathrm{CH}_{\text {Porph. }}\right), 8.70\left(8 \mathrm{H}, \mathrm{s}, \mathrm{CH}_{\text {Ph.-Porph. }}\right), 8.84(2 \mathrm{H}, \mathrm{s}, \mathrm{ArOH}), 8.85-$ $8.88\left(4 \mathrm{H}, \mathrm{m}, \mathrm{CH}_{\text {Porph. }}\right), 8.93(2 \mathrm{H}, \mathrm{d}, \mathrm{NHCO}), 9.27\left(4 \mathrm{H}, \mathrm{d}, \mathrm{CH}_{\text {Porph. }}\right)$.

\section{Results and Discussion}

The presence of substituents of different types has an influence on almost all physico-chemical and spectral properties of the compounds. The experimental data (elemental analysis, mass spectrometry, ${ }^{1} \mathrm{H}$ NMR spectroscopy) suggest that lanthanide ions form 1:1 complexes with ligands $\mathrm{L}^{1} \mathrm{H}_{2}-\mathrm{L}^{5} \mathrm{H}_{2}$. In this case the complexes include an anion $\left(\mathrm{Cl}^{-}\right)$ of starting salt. In complexes $\mathrm{LnL}^{1} \mathrm{Cl}-\mathrm{LnL}^{5} \mathrm{Cl}$ the lanthanide coordination unit is formed by the replacement of the labile hydrogen atoms of phenolic groups and oxygen atoms of ether and carbonyl fragments, and an appropriate quantity of solvent molecules with the realization of the coordination numbers 7-9. The coordination units of complexes $\mathrm{Ln}_{2} \mathrm{~L}^{1} \mathrm{Cl}_{2}$, as well as the starting lanthanide porphyrins, were formed by the interaction with the chloride anion (extra-ligand), four nitrogen atoms of the tetrapyrrole cycle and the corresponding amount of solvent molecules.
The analysis of ${ }^{1} \mathrm{H}$ NMR spectra of complexes with diamagnetic lutetium ion, and their comparison with the spectra of the ligands reveal some structural changes, which take place upon complexation. The signals of the protons of aromatic rings $(6.92,7.10$ and $6.89 \mathrm{ppm}, 7.03 \mathrm{ppm})$ and methylene groups $(3.52,4.20$ and $3.45 \mathrm{ppm}, 3.95 \mathrm{ppm})$ of ligands $\mathrm{L}^{4} \mathrm{H}_{2}$ and $\mathrm{L}^{5} \mathrm{H}_{2}$ found in downfield in comparison with the $\mathrm{L}^{2} \mathrm{H}_{2}$ and $\mathrm{L}^{3} \mathrm{H}_{2}$. Such shift, along with large constants of spin-spin interaction between protons of $\mathrm{Ar}-\mathrm{CH}_{2}-\mathrm{Ar}$ (13.3813.76), indicate the distortion of the "cone" conformation, which is connected with a change in dihedral angles between the tert-butylphenolic fragments. Thus, when the length of the alkyl radical increases the degree of distortion of the conformation of calix[4] arene increases also. The significant distortion of the conformation also occurs in the case of the bulky porphyrin substituents. The formation of complexes $\mathrm{LuL}^{1} \mathrm{Cl}-\mathrm{LuL}^{5} \mathrm{Cl}$ caused an upfield shift of the signals of tertbutyl proton $(\Delta \delta 0.05-0.21 \mathrm{ppm})$ with the keeping of their amount, which indicates less distortion of conformation of the complex in comparison with the ligand. The disappearance of the signals of protons of phenolic groups and the downfield shift of signals of protons of $\mathrm{O}-\mathrm{CH}_{2}-\mathrm{CO}$ groups of complexes $(\Delta \delta=0.11-0.20 \mathrm{ppm})$ confirm their participation in the complex formation. But in the case of complex $\mathrm{Lu}_{2} \mathrm{~L}^{1} \mathrm{Cl}_{2}$ the signals of calix[4] arene subunit does not change practically in comparison with the ligand. At the same time, the singlet of NH-protons of the pyrrole fragments disappears that specifies on their replacement upon complex formation. Besides, the signals of protons in the $\beta$-positions of porphyrinates are downfield shifted due to redistribution of electron density in the porphyrinate fragments. It should be noted that all ligands and complexes have the "cone" or "distorted cone" conformations.

The absorption spectra of all compounds (Table 1) are characterized by the broad bands with maxima at 270-290 $\mathrm{nm}\left(37000-38500 \mathrm{~cm}^{-1}, \lg \varepsilon=4.1-4.5\right)$, which correspond to the $\pi \rightarrow \pi^{*}$ - transitions of the calix[4]arene macrocycle. The absorption spectrum of calix-diporphyrin $\mathrm{L}^{1} \mathrm{H}_{2}$ contains the typical bands from the two macrocyclic fragments. The absorption band of calix[4]arene chromophore is observed in the UV region $\left(\lambda_{\text {max }}=274 \mathrm{~nm}, \lg \varepsilon=3.82\right)$; in contrast, the Soret band $\left(\lambda_{\max }=417 \mathrm{~nm}, \lg \varepsilon=4.91\right)$ and four $Q$-bands of the porphyrin macrocycle are recorded in the visible region. The bands of porphyrin fragments exhibit blue shifts in comparison with the spectrum of the starting monoaminoporphyrin: $\Delta \lambda_{\text {Soret }}=2 \mathrm{~nm}$ and $3-8 \mathrm{~nm}$ for $Q$-bands, that indicates the intramolecular interaction between two porphyrin fragments. ${ }^{[10]}$ The absorption spectra of benzimidazole substituted ligands $\mathrm{L}^{2} \mathrm{H}_{2}-\mathrm{L}^{5} \mathrm{H}_{2}$ display two narrow bands at $278-281$ and $284-286 \mathrm{~nm}$, and the increasing number of methylene groups does not affect the band positions and the molar extinction coefficients. Hence, the ratio of the intensities of the bands remains constant.

The absorption spectrum of the complex $\mathrm{LnL}^{1} \mathrm{Cl}$ in the region $250-300 \mathrm{~nm}$ is similar to that of the ligand, but is characterized by the additional band at $\lambda_{\max }=312-315 \mathrm{~nm}$ $(\lg \varepsilon=2.48)$, indicating (according ${ }^{[1]}$ ) the participation of phenolic groups in the complex formation. The structure of bands of porphyrin fragments does not change practically in contrast to the binuclear complex $\mathrm{Ln}_{2} \mathrm{~L}^{1} \mathrm{Cl}_{2}$. Soret bands in the absorption spectrum of $\mathrm{Ln}_{2} \mathrm{~L}^{1} \mathrm{Cl}_{2}$ are red shifted 
Table 1. The spectral-luminescent properties of ligands $\left(10^{-5} \mathrm{M}, \mathrm{CHCl}_{3}\right)$.

\begin{tabular}{cccccc}
\hline Ligand & $\lambda, \mathrm{nm}(\lg \varepsilon)$ & $\lambda_{\mathrm{ff}}, \mathrm{nm}$ & $E_{\mathrm{s}}, \mathrm{cm}^{-1}$ & $\lambda_{\mathrm{ph}}, \mathrm{nm}$ & $E_{\mathrm{T}}, \mathrm{cm}^{-1}$ \\
\hline $\mathrm{L}^{1} \mathrm{H}_{2}$ & $274(3.82)$ & 650 & 15400 & 846 & 11800 \\
& $417(4.91)$ & 717 & & & \\
& $515(3.63)$ & & & & \\
& $550(3.35)$ & & & & \\
& $590(3.12)$ & & & & \\
& $646(2.91)$ & & & & \\
\hline $\mathrm{L}^{2} \mathrm{H}_{2}$ & $278(4.51)$ & 416 & 24050 & 430 & 23250 \\
& $284(4.48)$ & & & & \\
\hline $\mathrm{L}^{3} \mathrm{H}_{2}$ & $280(4.27)$ & 410 & 24400 & 427 & 23400 \\
& $286(4.31)$ & & & & \\
\hline $\mathrm{L}^{4} \mathrm{H}_{2}$ & $281(4.18)$ & 408 & 24500 & 425 & 23500 \\
& $286(4.36)$ & & & & \\
\hline $\mathrm{L}^{5} \mathrm{H}_{2}$ & $281(4.15)$ & 405 & 24700 & 425 & 23500 \\
& $286(4.21)$ & & & & \\
\hline
\end{tabular}

$\left(\Delta \lambda_{\text {Soret }}=6-8 \mathrm{~nm}\right)$ and reduction of the number of "visible" bands up to two is observed (these changes are characteristic for metalloporphyrins). The absorption spectra of complexes of the same ligands with different lanthanides ( $\mathrm{Yb}, \mathrm{Er}, \mathrm{Lu})$ are identical, indicating that the type of coordination mode of the lanthanide ion does not change in the series. The appearance of the bands at 312-320 nm $(\lg \varepsilon=3.75-3.85)$ in the absorption spectra of the complexes $\mathrm{LnL}^{2} \mathrm{Cl}-\mathrm{LnL}^{5} \mathrm{Cl}$, similar to the previous compounds, testifies to participation of $\mathrm{OH}$ groups of the ligands in the complex formation.

The fluorescence spectra of ligands and complexes also differ from each other. It should be noted that in the spectrum of $\mathrm{L}^{1} \mathrm{H}_{2}$ the fluorescence from calix[4] arene moiety is not observed due to the intense absorption of porphyrin substituents in this region. The fluorescence with maxima at 650 and $717 \mathrm{~nm}$ and low-temperature $(77 \mathrm{~K})$ phosphorescence with a maximum at $846 \mathrm{~nm}$ are registered for this ligand.

Table 2. The spectral-luminescent properties of lutetium complexes $\left(10^{-5} \mathrm{M}, \mathrm{CHCl}_{3}\right)$.

\begin{tabular}{|c|c|c|c|c|c|}
\hline Complex & $\lambda, \operatorname{nm}(\lg \varepsilon)$ & $\lambda_{\mathrm{f}}, \mathrm{nm}$ & $E_{\mathrm{s}}, \mathrm{cm}^{-1}$ & $\lambda_{\mathrm{ph}}, \mathrm{nm}$ & $E_{\mathrm{T}}, \mathrm{cm}^{-1}$ \\
\hline $\mathrm{LuL}^{1} \mathrm{Cl}$ & $\begin{array}{c}280(3.42) \\
312(2.48) \\
418(5.1) \\
516(4.2) \\
552(3.75) \\
591(3.46) \\
638(3.43) \\
\end{array}$ & $\begin{array}{l}646 \\
710\end{array}$ & 15500 & 845 & 11800 \\
\hline $\mathrm{Lu}_{2} \mathrm{~L}^{1} \mathrm{Cl}_{2}$ & $\begin{array}{l}278(3.82) \\
425(4.90) \\
557(3.52) \\
595(3.12)\end{array}$ & $\begin{array}{l}648 \\
710\end{array}$ & 15400 & 852 & 11700 \\
\hline $\mathrm{LuL}^{2} \mathrm{Cl}$ & $\begin{array}{l}280(4.19) \\
286(4.20) \\
316(3.75)\end{array}$ & 423 & 23700 & 435 & 23000 \\
\hline $\mathrm{LuL}^{3} \mathrm{Cl}$ & $\begin{array}{l}280(4.20) \\
284(4.22) \\
319(3.85) \\
\end{array}$ & 415 & 24100 & 430 & 23250 \\
\hline $\mathrm{LuL}^{4} \mathrm{Cl}$ & $\begin{array}{l}280(4.20) \\
286(4.36) \\
318(3.65)\end{array}$ & 412 & 24300 & 430 & 23250 \\
\hline $\mathrm{LuL}^{5} \mathrm{Cl}$ & $\begin{array}{l}280(4.20) \\
286(4.37) \\
317(3.70)\end{array}$ & 410 & 24400 & 427 & 23400 \\
\hline
\end{tabular}

These maxima are blue shifted (14.6 and $16 \mathrm{~nm}$, respectively) in comparison with the starting monoaminoporphyrin. The broad band of fluorescence of benzimidazole derivatives is registered only at $77 \mathrm{~K}$ in the region $416-405 \mathrm{~nm}$ (the maximum shifts to shorter wavelengths with increasing number of methylene groups of alkyl radical). The positions of the phosphorescence maxima $\left(\lambda_{\max }=430-425 \mathrm{~nm}\right)$ are changed in a similar way, and can be observed only with the application of the time delay (50 ms) and the low temperature (77 K).

The molecular fluorescence and phosphorescence of lutetium complexes (Table 2) were recorded under similar conditions. The fluorescence of calix[4]arene component in the complex $\mathrm{LuL}^{1} \mathrm{Cl}$ is not observed; the fluorescence bands of porphyrin substituents exhibit blue shifts on 4 and $7 \mathrm{~nm}$ by comparison with the ligand. The fluorescence maxima at 648 and $710 \mathrm{~nm}$ and a band of phosphorescence (maximum at $852 \mathrm{~nm}$ ) are observed for the binuclear complex $\mathrm{Lu}_{2} \mathrm{~L}^{1} \mathrm{Cl}_{2}$. As well as for benzimidazole calix[4]arenes, the fluorescence and phosphorescence of complexes $\mathrm{LuL}^{2} \mathrm{Cl}-\mathrm{LuL}^{5} \mathrm{Cl}$ were divided using the low-temperature conditions and time delay (50 ms). The observed red shifts of the bands of fluorescence and phosphorescence of the lutetium complexes show a slight decrease of energy of singlet $E_{\mathrm{S}}\left(200-350 \mathrm{~cm}^{-1}\right)$ and triplet $E_{\mathrm{T}}$ $\left(100-250 \mathrm{~cm}^{-1}\right)$ levels in comparison with the ligands.

It is known ${ }^{[11]}$ that the efficiency of $4 f$-luminescence of lanthanide complexes depends on the location of the lowest triplet states of ligands. The data (Table 1) clearly demonstrate that the luminescence, which realized by the mechanism of intramolecular energy transfer from the organic part of the complex to the resonance levels of ions $\mathrm{Yb}^{\mathrm{III}}\left({ }^{2} \mathrm{~F}_{5 / 2}, 10300 \mathrm{~cm}^{-1}\right)$ and $\mathrm{Er}^{\mathrm{III}}\left({ }^{4} \mathrm{I}_{13 / 2}, 6500 \mathrm{~cm}^{-1}\right)$, is possible for all ligands, which triplet levels are above the excited energy levels of $\mathrm{Ln}^{\mathrm{III}}$.

The $4 f$-luminescence of Er ${ }^{\mathrm{III}}$ and $\mathrm{Yb}^{\mathrm{III}}$ is realized in the homo- and dinuclear complexes (Table 3). The luminescence quantum yield of the complex $\mathrm{YbL}^{1} \mathrm{Cl}$ is less than 1.7 times compared with $\mathrm{Yb}_{2} \mathrm{~L}^{1} \mathrm{Cl}_{2}$ that can be the result of energy transfer from the excited levels of calix[4]arene macrocycle to porphyrin subunits. The coincidence of the excitation spectra of $4 f$-luminescence and the absorption spectra of the complexes $\mathrm{YbL}^{2} \mathrm{Cl}-\mathrm{YbL}^{5} \mathrm{Cl}$ indicates the sensitization of $4 f$-luminescence of ytterbium by organic chromophore. The growing number of methylene groups in the row $\mathrm{YbL}^{2} \mathrm{Cl}-\mathrm{YbL}^{5} \mathrm{Cl}$ leads to the increase in quantum yield of $4 f$-luminescence up to $\mathrm{n}=3\left(\mathrm{YbL}^{2} \mathrm{Cl}-\mathrm{YbL}^{4} \mathrm{Cl}\right)$, but upon further elongation $\left(\mathrm{n}=4, \mathrm{YbL}^{5} \mathrm{Cl}\right)$ the luminescence signal notably decreases.

Table 3. Characteristics of $4 f$-luminescence of $\mathrm{Yb}^{\mathrm{III}}$ in complexes (Error is $\pm 10 \% ; \mathrm{CHCl}_{3}, 10^{-5} \mathrm{M}$ ).

\begin{tabular}{|c|c|c|c|c|}
\hline \multicolumn{2}{|c|}{ Mononuclear complexes } & \multirow{2}{*}{\multicolumn{3}{|c|}{$\begin{array}{r}\text { Heteronuclear complexes } \\
\qquad \mathrm{I}_{\text {lum }}, \%\end{array}$}} \\
\hline Compound & $\varphi \times 10^{3}$ & & & \\
\hline $\mathrm{YbL}^{1} \mathrm{Cl}$ & 2.8 & \multirow{2}{*}{ Compound } & \multirow{2}{*}{ Solid } & \multirow{2}{*}{ Solution } \\
\hline $\mathrm{Yb}_{2} \mathrm{~L}^{1} \mathrm{Cl} 2$ & 4.7 & & & \\
\hline $\mathrm{YbL}^{2} \mathrm{Cl}$ & 3.8 & $\mathrm{YbCu}_{2} \mathrm{~L} 1 \mathrm{Cl}$ & 14 & - \\
\hline $\mathrm{YbL}^{3} \mathrm{Cl}$ & 4.2 & $\mathrm{YbZn}_{2} \mathrm{~L} 1 \mathrm{Cl}$ & 115 & 84 \\
\hline $\mathrm{YbL}^{4} \mathrm{Cl}$ & 4.4 & $\mathrm{Yb}\left(\mathrm{CuCl}_{2}\right) \mathrm{L}^{3} \mathrm{Cl}$ & 78 & 97 \\
\hline $\mathrm{YbL}^{5} \mathrm{Cl}$ & 2.9 & $\mathrm{Yb}\left(\mathrm{ZnCl}_{2}\right) \mathrm{L}^{3} \mathrm{Cl}$ & 260 & 168 \\
\hline
\end{tabular}


For the first time it was detected the $4 f$-luminescence of $\mathrm{Er}^{\mathrm{III}}\left({ }^{4} \mathrm{I}_{13 / 2} \rightarrow{ }^{4} \mathrm{I}_{15 / 2}\right.$ transition $)$ in the complexes $\mathrm{ErL}^{2} \mathrm{Cl}-\mathrm{ErL}^{3} \mathrm{Cl}$ and $\mathrm{Er}_{2} \mathrm{~L}^{1} \mathrm{Cl}_{2}$. It was found that the changes of the intensity $4 f$ luminescence of $\mathrm{Er}^{\mathrm{III}}$ in the investigated complexes are similar to the ones observed in a row of ytterbium complexes.

The formation of heteronuclear complexes is based on the polytopic nature of functionalized calix[4]arenes $\mathrm{L}^{1} \mathrm{H}_{2}$ $\mathrm{L}^{5} \mathrm{H}_{2}$, which is provided by substituents in the lower rim. The $f$ - $d$-heteronuclear complexes were obtained based on 1,3-disubstituted $p$-tert-butylcalix[4] arenes $\left(\mathrm{L}^{1} \mathrm{H}_{2}\right.$ and $\left.\mathrm{L}^{3} \mathrm{H}_{2}\right)$ modified by porphyrin and benzimidazole fragments. Copper and zinc $\left(\mathrm{MCl}_{2}\right)$ have been selected as the $d$-metals (so called "test"-ions) due to different structure of the electron shell and, at the same time, almost identical ionic radii. In addition, the choice of $d$-metals was made taking into account the specific spectroscopic properties of their complex, in particular, with porphyrins.

To obtain the heteronuclear complexes based on the $\mathrm{L}^{1} \mathrm{H}_{2}$ and $\mathrm{L}^{3} \mathrm{H}_{2}$ were used their homocomplexes as "blocks": $\mathrm{M}_{2} \mathrm{~L}^{1} \mathrm{H}_{2}$ and $\mathrm{YbL}^{3} \mathrm{Cl}$ (Figure 1). Heteronuclear complexes $\mathrm{LnM}_{2} \mathrm{~L}^{1} \mathrm{Cl}$ were synthesized based on calix[4]arene modified porphyrin fragments according to the method similar with mononuclear complex $\mathrm{LnL}^{1} \mathrm{Cl}$. $\mathrm{LnM}_{2} \mathrm{~L}^{3} \mathrm{Cl}$ was isolated from the $\mathrm{CH}_{3} \mathrm{OH}$-solution containing complex $\mathrm{LnL}^{3} \mathrm{Cl}$ and an excess of $d$-metal chloride (1:5).

The absorption spectra of lanthanide-containing complexes with $d$-metals $\mathrm{LnM}_{2} \mathrm{~L}^{1} \mathrm{Cl}$ compared with mononuclear complexes are characterized by the small blue shift $(\Delta \lambda=4-6 \mathrm{~nm})$ of the bands $\left(\pi \rightarrow \pi^{*}\right.$-transitions in calix [4]arene macrocycle) without change of intensity. This is due to the fact that additional complexation on the lower rim of the ligand changes the symmetry of the complexes, but the coordination unit of lanthanide remains unchanged. Only two $Q$-bands in the visible region are observed in the spectra of complexes $\mathrm{LnM}_{2} \mathrm{~L}^{1} \mathrm{Cl}$ instead of four absorption bands in the spectra of $\mathrm{LnL}^{1} \mathrm{Cl}$ that confirms the formation of $d$-metal porphyrins. The absorption spectra of heteronuclear complexes with $\mathrm{LnL}^{3} \mathrm{Cl}$ slightly differ from the absorption spectrum of the starting mononuclear complex. Namely, the ratio of intensities of the calix[4]arene bands slightly changes that can be attributed to the interaction of $d$-metal ions with benzimidazole groups of the lower rim. These deviations are insignificant and indicate that the formation of the heteronuclear complexes with $d$-metal do not affect the coordination unit of lanthanide in the "block"-complex.

The molecular fluorescence and phosphorescence spectra of heteronuclear complexes with calix[4]arenes $\mathrm{L}^{1} \mathrm{H}_{2}$ and $\mathrm{L}^{3} \mathrm{H}_{2}$ were recorded in solution. The bands of the calix[4] arene fragment are observed only for the complexes with benzimidazole derivative: fluorescence - at 420-450 nm and phosphorescence - at 450-470 $\mathrm{nm}$. The obtained data show that notable decrease in energy of the singlet and triplet levels $\left(\mathrm{T}_{\mathrm{Cu}}=22630 \mathrm{~cm}^{-1}, \mathrm{~T}_{\mathrm{Zn}}=21800 \mathrm{~cm}^{-1}\right)$ is observed in both cases. The fluorescence spectra of heteronuclear complexes $\mathrm{LuM}_{2} \mathrm{~L}^{1} \mathrm{Cl}$ contain two bands with maxima at the 600-605 nm $(0-0)$ and $648-652 \mathrm{~nm}(0-1)$ with a different distribution of intensities. It was shown that the bands are of narrow form and blue shifted $(2-5 \mathrm{~nm})$ in frozen solutions.
The $4 f$-luminescence of $\mathrm{Yb}^{\mathrm{III}}$ ions in all heteronuclear complexes with $\mathrm{L}^{1} \mathrm{H}_{2}$ and $\mathrm{L}^{3} \mathrm{H}_{2}$ was observed in solution and in solid samples (Table 3 ). The presence of zinc does not affect on the $4 f$-luminescence intensity ytterbiumcontaining complexes with $\mathrm{L}^{1} \mathrm{H}_{2}$ both in solid state and in solution. But in $\mathrm{Cu}-\mathrm{Yb}$-complexes the quenching of the 4 -luminescence takes place. In $\mathrm{Zn}$-Yb-complex with $\mathrm{L}^{3} \mathrm{H}_{2}$ the intensity of the $4 f$-luminescence is increased in 1.7 and 2.6 times in the solution and solid sample, respectively. Evidently, this fact is connected with the energy of the exited levels of $d$-metals: $5015 \mathrm{~cm}^{-1}$ and $17520-19510 \mathrm{~cm}^{-1}$ for copper and zinc compounds, respectively. ${ }^{[12]}$ Thus, the $4 f$-luminescence intensity is changed little or is increased (complexes with zinc) if the excited level of the $d$-metal is located above the emitting level of lanthanides. Low-lying excited levels of copper are "acceptors" of $4 f$-luminescence of lanthanides, contributing to its effective role in process of quenching.

\section{Conclusions}

The mono- and heteronuclear lanthanide-containing complexes on the basis of 1,3-disubstituted p-tertbutylcalix[4]arenes modified with porphyrins and benzimidazole fragments were obtained. It was shown that in these complexes the $4 f$-luminescence of $\mathrm{Er}^{\mathrm{III}}$ and $\mathrm{Yb}^{\mathrm{III}}$ ions is realized. The heteronuclear $\mathrm{Yb}-\mathrm{Cu}$ and $\mathrm{Yb}-\mathrm{Zn}$ complexes on the basis of calix[4]arenes $\mathrm{L}^{1} \mathrm{H}_{2}$ and $\mathrm{L}^{3} \mathrm{H}_{2}$ were also sensitized. It was established that the relative positions of excited levels of $d$ - and $f$-metal have a significant influence on the $4 f$-luminescent characteristics of heteronuclear complexes.

Acknowledgements. The authors are grateful of the National Academy of Sciences of Ukraine for funding (Project No. 6.22.7.43).

\section{References}

1. Gutsche C. Calixarenes. London: Royal Society of Chemistry, 2008. $276 \mathrm{p}$.

2. Vicens J., Harrowfield J., Baklouti L. Calixarenes in the Nanoworld. Dordrecht: Springer-Verlag, 2007. 395 p.

3. Dudic M., Lhovak P., Stibor I., Petrickova H., Sykora J., Lang K. Tetrahedron 2003, 53, 2409-2415.

4. Beer P., Drew M., Kan M., Leeson P., Ogden M., Williams G. Inorg. Chem. 1996, 35, 2202-2211.

5. Varnek A., Wipff G. J. Phys. Chem. 1993, 97, 10840-10848.

6. Cheriaa N., Abidi R., Vicens J. J. Incl. Phenom. Macrocycl. Chem. 2008, 60, 303-312.

7. Dudic M., Lhovak P., Stibor I., Dvorakova H., Lang K. Tetrahedron 2002, 58, 5475-5482.

8. Alekseeva E., Lukyanenko A., Basok S., Mazepa A., Gren’ A. Russ. J. Org. Chem. 2010, 46, 1403-1408.

9. Shushkevich I.K., Dvornikov S.S., Kachura T.F., Solov'ev K.N. J. Appl. Spectr. 1981, 35, 1109-1113.

10. Esch J., Peters A., Nolte R. J. Chem. Soc., Chem. Commun. 1990, 638-639.

11. Malta O. J. Luminescence 1997, 71, 229-236.

12. Palmer R., Piper T. Inorg. Chem. 1966, 5, 864-878. 